\title{
Preparing Teachers for Plurilingualism through Language Awareness
}

Francis John Troyan

\section{(2) OpenEdition \\ Journals}

Electronic version

URL: http://journals.openedition.org/trema/3219

DOI: $10.4000 /$ trema.3219

ISSN: 2107-0997

\section{Publisher}

Faculté d'Éducation de l'université de Montpellier

\section{Printed version}

Date of publication: 1 November 2014

Number of pages: 86 - 101

ISSN: 1167-315X

\section{Electronic reference}

Francis John Troyan, «Preparing Teachers for Plurilingualism through Language Awareness », Tréma [Online], 42 | 2014, Online since 16 June 2015, connection on 21 April 2019. URL : http:// journals.openedition.org/trema/3219; DOI : 10.4000/trema.3219

This text was automatically generated on 21 April 2019

Trema 


\title{
Preparing Teachers for Plurilingualism through Language Awareness
}

\author{
Francis John Troyan
}

\section{Introduction}

1 Plurilingualism has been identified as a way of life in Europe (Beacco, 2005, p. 15). Therefore, developing the plurilingual identity and awakening the plurilingual capacity that lies within the individual (Beacco \& Byram, 2003) has become the focus of language education in Europe. Given that plurilingual identities «are situated in time, discourse, and are context based» (Oliveira \& Ançã, 2009, p. 405), pedagogies that make «visible» (Bernstein, 1996) to learners the ways in which language works across multiple cultural contexts are needed to realize the goals of plurilingualism. Developing such language awareness among learners calls for a reorientation of language teacher preparation to develop among novice teachers not only language awareness (e.g., Borg, 1994; Pomphrey \& Burley, 2009), but also the ability to facilitate learning in linguistically diverse classrooms (Le Nevez, Hélot, \& Ehrhart, 2010).

2 To this end, the present study describes the developing language awareness of a fourth grade teacher of Spanish as she implemented a genre-based approach to writing instruction that focused on the touristic landmark description genre. The genre theory informed by systemic functional linguistics (SFL, Halliday \& Matthiessen, 2004, 2013) guided the development of the instructional intervention that the teacher implemented. This genre theory and SFL have been cited as a means for developing essential language awareness among language teachers (e.g., Gebhard, 2010; Troyan, 2012). The present study is part of a larger study of the design and implementation of a genre-based model of instruction, which has been described elsewhere (Troyan, 2014).

3 This qualitative research informs the growing need in France, Europe, and beyond for teacher preparation to address practices that develop plurilingualism, the theme of this issue, in two ways. First, the realization of the goals of plurilingualism calls for 
developing language teachers who can «help students to recover (in order to become aware of) the contexts in which their communicative/linguistic experiences take place and the asset these represent for an evolving plurilingual competence» (Oliveira \& Ançã, 2009, pp. 412-413).

The genre theory informed by SFL, which will be described further below, offers a linguistic framework for describing language use in context and therefore is highly compatible for promoting the language awareness necessary to develop plurilingual competence ${ }^{1}$.

5 Second, this work, given its focus on the integration of language and content, is aligned with the objective of content and language integrated learning (CLIL) to promote plurilingual competence (e.g., Lorenzo, 2013; Lorenzo, Casal, \& Moore, 2010; Ruiz de Zarobe, 2013).

CLIL has been conceived to enhance language competence and communication in an ever-growing multilingual society where, in the case of the EU, 23 official languages coexist with more than 60 regional or minority languages, some of which have official status (Basque, Catalan and Sami, among others). Additionally, we need to include hundreds of other languages which immigrant communities provide. This multilingual diversity calls for an educational approach that can become an appropriate vehicle for intercultural communication. Consequently, CLIL can be understood as a truly European approach for the integration of language and content in the curriculum as part of the international mosaic of multilingualism (Ruiz de Zarobe, 2013, p. 233).

6 In sum, the present study is positioned at the intersection of the work in CLIL and plurilingualism, both of which have called for the development of strategic language awareness among language teachers. In the study presented here, the teacher's language awareness was developed according the genre theory of the Sydney School of Linguistics. This theory, which was informed by SFL, is briefly described in the following section.

\section{Theoretical Framework}

7 Genre is operationalized in this study according to the theory developed by the Sydney School of Linguistics through research that described the writing of students in Sydney, Australia public schools (Martin \& Rose, 2008). Martin, Christie, and Rothery (1987) define genres as:

social processes because members of a culture interact with each other to achieve them; as goal oriented because they have evolved to get things done; and as staged because it usually takes more than one step for participants to achieve their goals (p. 59).

8 In addition, SFL (Halliday \& Matthiessen, 2004, 2013) was enlisted in the theoretical framework for this work. SFL is a theory of language that can function as a highly descriptive metalanguage for teachers because of «(i) its focus on grammar as a meaningmaking resource and (ii) its focus on text as semantic choice in social context» (Martin, 2009, p. 11). SFL offers three metafunctions through which language use in context can be described at the level of the clause. According to the genre theory informed by SFL, the genre of any text, written or spoken, consists of (1) field, the subject matter of the text, construed through the ideational metafunction, (2) tenor, the relationship between those involved in the interaction, construed through the interpersonal metafunction, and (3) mode, the channel of communication (Derewianka, 1991, p. 18), construed through the 
textual metafunction (Halliday \& Matthiessen, 2004, 2013; Martin, 2009). When viewed from the level of the whole text, field, tenor, and mode can be seen as the register variables of the text through which meaning is made using the language system in a given situation (Derewianka, 1991; Derewianka \& Jones, 2012; Martin, 1992). A comprehensive discussion of the role of SFL is beyond the scope of this article. See Troyan $(2013,2014)$ for more details.

\section{Review of Relevant Research}

The teacher's developing awareness of genre and SFL as she learned to teach the linguistic and organizing features of the touristic landmark description genre was the focus of the present study. This particular genre was chosen because it was appropriate for 1) the instructional goals of the teacher's curriculum, 2) the students involved, and 3) the overarching standards for learning. Interest in genre theory and SFL has been inspired by recent educational standards in the United States that seek to develop students' ability to interpret and write a variety of texts types (National Governors Association, 2010). Integrating genre theory and SFL into the teaching of reading and writing in the foreign language classroom would equip teachers and students with powerful interpretive tools with which to better comprehend and create texts (e.g., Troyan, 2014). In the European context, recent scholarship has infused this genre theory and SFL in the writing research pertaining to content and language integrated learning (CLIL) (Llinares \& Whittaker, 2010; Whittaker, Llinares, \& McCabe, 2011), an instructional approach that has been promoted as a means for developing plurilingualism (e.g., Lorenzo, 2013; Ruiz de Zarobe, 2013) in a multilingual Europe.

10 A group of CLIL scholars have used SFL as the analytical approach in their writing research (e.g., Llinares \& Whittaker, 2010; Whittaker, Llinares \& McCabe, 2011) and, most pertinent to this discussion, the genre theory informed by SFL. Llinares and Whittaker (2010) investigated the students' language use in the writing of historical account and historical explanation genres. Based on their analysis of student writing guided by SFL, the researchers concluded that teachers need training to become more aware of «the linguistic features required for the representation of content in their subject» (p. 141). Expanding the discussion of historical writing in CLIL settings, Morton (2010) outlined several example genres that textbooks and curricula require students to write: explaining about people, writing a tale about an historical figure, writing a biography about an historical figure. Yet, as the author highlights, history textbooks and therefore the curricula include «no explicit guidance or instruction on how to construct the relevant genres» (p. 88). The author does not outline a specific genre pedagogy; however in the introduction, the Sydney School approach (Martin \& Rose, 2008) is referenced in calling for «building field knowledge, and deconstructing and constructing relevant genres» in CLIL classrooms (Morton, 2010, p. 85), echoing similar calls elsewhere in the CLIL literature (Lorenzo, 2013; Whittaker et al., 2011).

11 Thus, the CLIL literature highlights the need for the investigation of genre-based pedagogies. Furthermore, the literature in the related field of content-based instruction (CBI) in foreign languages in the United States likewise suggests the exploration of genre theory and functional linguistics to enhance teacher training in the field. As Cammarata and Tedick have concluded from the perspectives of research in CBI (Cammarata \& Tedick, 2012) and immersion education (Tedick \& Cammarata, 2012), language 
development in such programs is «inextricably tied to teacher practice» (Tedick \& Cammarata, 2012, p. S43). The development of language awareness is critical to promote a linguistic «awakening» (Cammarata \& Tedick, 2012, pp. 260-261) within the teacher, which enables her incorporate that knowledge of language into her practice. Despite the potential of developing such language awareness, no research has explored the experience of a teacher developing language awareness through a genre-based writing pedagogy in an early foreign language CLIL or non-CLIL setting.

\section{The Study}

The focus the present study was to describe the teacher's experience implementing a genre-based pedagogy by answering the following research question: What were the reactions of the teacher as she implemented the new genre-based approach with her students?

\section{1. Setting}

13 The present study was conducted in a fourth grade Spanish classroom at a university laboratory school in the eastern United States during the spring semester of 2012. At the time of the study, this K-8 private school enrolled approximately 350 students. The student population of this school reflected that of the surrounding areas: approximately 60\% are Caucasian, 8\% African American, 11\% Asian American or Pacific Islander, 5\% Hispanic and other racial minorities, and $14 \%$ multiracial.

This Spanish as a foreign language program was classified as a language-driven program (Met, 1999) in which meaningful content was infused through an authentic text. The Spanish teacher was an itinerant teacher who provided fifteen minutes of instruction daily in all classrooms kindergarten through fifth grade. The Spanish curriculum was composed of semester long thematic units (e.g., A Trip to Perú, All About Me) that integrated meaningful cultural content through authentic texts. Curriculum development followed the recommendations for proficiency-based instruction for young language learners (Curtain \& Dahlberg, 2010; Shrum \& Glisan, 2010). In other words, lessons were designed thematically considering the contexts, functions, and texts appropriate for the novice learners.

\section{2. The teacher}

15 At the time of the present study, the teacher was in her third year of teaching K-5 Spanish at the laboratory school. A recent graduate of the MAT program at the university, she was trained in foreign language teaching methodology, language assessment design and implementation, and the teaching of foreign languages in elementary schools. The present study emerged from an on-going partnership between the teacher and the researcher. During the spring of 2011, the teacher and the researcher began to explore the integration of genre and SFL in teaching students to interpret and write texts in Spanish. Together they conducted a pilot study of a genre-based unit of instruction in which the teacher led her students through a process of deconstructing the genre - an instructional video on recycling from Spain - co-constructing a new text in the same genre, and independently writing the script for their own instructional videos in Spanish. By the end of the unit, the students were able to apply knowledge of the genre as they 
created their own texts. The texts that the students created were scripts for their own recycling video, which explained how to recycle to Spanish-speaking newcomers to their city. This experience led to the subsequent design of a genre-based pedagogy that the teacher implemented in the spring semester 2012 to teach students to write in one genre, the tourisitic landmark description. The development of the pedagogy was informed by the work of the innovative educational and linguistic research of the Sydney School of Linguistics.

\section{3. The Genre-Based Pedagogy}

16 The genre-based pedagogies of the Sydney School of Linguistics (e.g., Martin, 2009; Rose \& Martin, 2012; Rothery, 1989, 1996) advocate a systematic apprenticeship in the interpretation and composition of texts. The pedagogies have been informed by the child language studies of Painter $(1984,1986)$ and Halliday $(1975,1993)$ in which the language development of children was found to be highly supported by interactions in joint activity with adults. Reflecting this nature of language development, the genre-based pedagogy is comprised of three phases: Deconstruction, Joint Construction, and Independent Construction (Matin, 2009; Martin \& Rose, 2007). In the Deconstruction phase, students are familiarized with the genre that they will eventually write. Students first consider What is going on in the text ? (Fang \& Schleppegrell, 2008). Using this knowledge of the genre, students later appropriate the functional knowledge about the genre to create their own version of the text at the end of the learning cycle. Once students are familiar with the genre, they begin to develop control through Joint Construction (Derewianka, 2003). In this phase, the teacher and students collaborate in creating the genre through an oral negotiation of the genre. As the students suggest a part of the text, the teacher records it noting the differences between the spoken and written versions of the genre (Derewianka \& Jones, 2012; Painter, 1986; Rothery, 1989). The final phase involves Independent Construction of the genre. At this point, the students apply their knowledge of the genre in a writing task completed without assistance. The application of the genre pedagogy of the Sydney School to teach students to write the touristic landmark description is described elsewhere by Troyan (2014).

\section{4. Data Sources and Analysis}

17 A case study design (Merriam, 1998) guided this study. Data sources included qualitative interviews, a dialogue journal between the teacher and the researcher, and researcher fieldnotes taken during the study. Throughout the 19 days of the study, the teacher and the researcher made entries each week in a dialogue journal. Qualitative interviews were conducted at two points during the study: halfway through the study and at the end of the study. During the interviews, the researcher asked initial questions based on the themes revealed in the dialog journal. Throughout the interviews, as particular themes emerged, the researcher encouraged deeper descriptions of those themes through the use of affirming backchannel cues (e.g., uh-huh), and the encouragement of dialogue with the overall goal of uncovering the «lived experience» (Cammarata, 2009; 2010; Cammarata \& Tedick, 2012) of the teacher. Data coding began with the interview transcripts because of the focus of the study on the teacher's experience with the genre-based pedagogy. The field notes were subsequently coded and served as a means of triangulation of the themes in the interview data. Finally, to increase the validity of the interpretations of the data, 
the researcher conducted formal and informal member checking (i.e., Yi, 2013). Informal member checking occurred throughout the study as the researcher shared emerging themes during the interviews, whereas formal member checking occurred at the end of the study during which the teacher had an opportunity to comment on the final report of the findings.

\section{5. Findings}

The findings in this section respond to the research question by describing the teacher's experience with genre-based pedagogy and the development of her genre awareness according to the following themes in the data: 1) Expanding notions of text interpretation, 2) Teacher's awareness of genre, and 3) Target language use.

\section{5. 1. Expanding notions of text interpretation}

The teacher highlighted her students' ability to make meaning of the touristic landmark description as one success of the unit of instruction. Some students were initially overwhelmed and distracted by the length of the text when introduced to it by the teacher. This distraction was apparent in student comments such as «I can't understand it » or «I can't read in Spanish». However, the teacher observed that because of her use of questioning and redirecting students in their interpretive activity, they were able to make meaning of the text in a more comprehensive way than they had in past interpretive tasks focused on discrete decoding skills such as key word identification and important ideas. The teacher, in her reflections on the interpretive process, indicated surprise at the ability of her students to be led in a meaning-making activity that challenged students to move beyond literal interpretations of a text. By telling students that they «don't have to understand every word», the teacher reinforced the goal of the task of interpretation and mitigated some of the anxiety experienced by students. Furthermore, the teacher perceived this use of enhanced questioning in an interpretive task as a shift in her instructional practice. Previous to this study, she had designed and framed her approach to interpretive tasks based on the framework of the Integrated Performance Assessment (IPA) comprehension guide (Glisan, Adair-Hauck, Koda, Sandrock, \& Swender, 2003). The IPA template used by the teacher only required novice level students to complete literal interpretation tasks such as identifying key words, important ideas, and the main idea of the text. Using this template the teacher noted: «[I] would have never have...[gone]...deeper into their interpretive mode...[I] just never before would have thought to probe that deeply». Therefore, the genre-based pedagogy that the teacher implemented expanded her view of her students' potential ability to interpret texts. The shift in the way teacher approached the instruction of text interpretation is attributable to her evolving awareness of genre.

\section{5. 2. Teacher's awareness of genre}

After the posttest was administered and before the student writing was scored, the teacher viewed her students' posttest writing and noted her impressions in the dialogue journal. During the post-study interview, the teacher reflected on her impressions of the students' change in writing performance. She noted that the posttest writing: 
was broken up into sections...the selection of vocabulary...even if some of them didn't have a hook phrase [a text feature highlighted during instruction], they were like The cathedral is magnificent or It is one of the most popular landmarks in Oakland. Whereas in the past, it was a lot of things like I like this You can do this here. My name is «blank».

21 In this analysis of the students' writing, the teacher demonstrates an awareness of a shift in the students' focus on purpose, use of the stages of the touristic landmark description genre, and movement away from first-person writing in the posttest. This awareness marks a shift in her thinking about her expectations for student writing from personalized writing to genre-specific literacy skills.

As opposed to her past practice, in which students wrote primarily in the first person reflecting her instructional focus on developing interpersonal speaking skills, this new focus on genre enabled the teacher to begin to explore and make explicit to her students the multiple ways in which meaning is made in texts from the target culture. In addition to her awareness of the change in her students' writing after having been exposed to critical features of the genre, the teacher began to explore ways of integrating her knowledge of genre into her design of instruction for other grade levels.

Beyond the work related to her teaching of the fourth grade class taught following genrebased pedagogy, the teacher applied her growing knowledge of genre in the design of instruction for other classes not involved in this study. In a unit on the Caribbean designed for her third grade students, she revised instruction in two ways. First, her knowledge of genre helped her to modify tasks in instruction and assessment to better align those tasks according to genre. In the unit of instruction on the Caribbean, she became aware of a disconnection between the text that she asked students to interpret and the text that students needed to write. Previously, students were asked to interpret a video about «Going to the Beach» and later create a brochure about vacationing in the Caribbean. Because of her awareness of genre, the teacher noted the key differences between the interpretive listening task involving the video and the presentational writing task involving the creation of a vacation brochure. To mitigate this genre differential in this unit of instruction, the teacher changed the genre in the interpretive task to a brochure. In this way, the genre addressed across the unit of instruction, the vacation brochure, remained consistent.

The second instance of the teacher's appropriation of her evolving genre awareness involved the integration of aspects of the genre pedagogy across her instructional practice. The teacher described revisions that she made to her approach to text-based instruction in a unit in her third grade class:

This time I chose an article that was about beaches of the Caribbean. It was geared toward tourists. It was a little different than a guidebook. It was like really enticing. It talked about all of these features that might entice people to visit. So we read that and talked about that. Then we did a very small co-construction. I wish we would have had more time [for the co-construction]. We thought of a title and we thought of a hook phrase. And then we thought of the sections. From what we talked about, it seemed that the sections were location, weather, activities, and wildlife. Then there was a closure, an ending in the form of a command like Come visit.

In addition to the work implemented in the fourth grade classroom involved in the present study, in this passage, the teacher depicted a transformation in her approach to instruction and assessment in another grade level. Specifically, she described the modifications that she made to her approach to the design of reading tasks by aligning 
them in terms of genre with writing tasks. Moreover, she had begun to incorporate the phases of the genre-based pedagogy - Deconstruction, Joint Construction, and Independent Construction - as her overarching approach to reading and writing instruction. Despite a lack of time to fully integrate the Joint Construction of the text in the third grade, the teacher planned to revise the curriculum for the following year to ensure that time allowed for a meaningful Joint Construction of the text. Thus, the genre pedagogy helped to raise the teacher's awareness of genre and its role in her overall instructional approach for developing students' ability to read and write in Spanish.

\section{5. 3. Target language use}

The teacher experienced a tension between maintaining target language use, guiding students through the interpretation of the text, and «doing it right», i.e, following the framework for the lessons that had been provided to her for the implementation of the unit of instruction. The teacher's desire to teach quality lessons that adhered to what she knows to be good practice - i.e., $90-100 \%$ of the class in the target language as defined by the American Council on the Teaching of Foreign Languages (ACTFL, 2013) - was in conflict with her novice status as a teacher of interpretive reading and presentational writing skills within 15-minute classes. The dialogue journal and interview data revealed this tension between the expectations for target language use and her perceived target language use during instruction. To investigate this tension, the percentage of time the teacher used English in each 15-minute class was compared to the use of the target language.

Table 1. Target language and English use during instruction

\begin{tabular}{|c|c|c|c|c|}
\hline \multirow{2}{*}{ Day } & \multicolumn{2}{|c|}{ English } & \multicolumn{2}{c|}{ Spanish } \\
\cline { 2 - 5 } & Percent & Minutes & Percent & Minutes \\
\hline 1 & -- & -- & -- & -- \\
\hline 2 & -- & -- & -- & -- \\
\hline 3 & 3.3 & .5 & 96.7 & 14.5 \\
\hline 4 & 3.3 & .5 & 96.7 & 14.5 \\
\hline 5 & 3.3 & .5 & 96.7 & 14.5 \\
\hline 6 & 60 & 9 & 40 & 4 \\
\hline 7 & 50 & 7.5 & 50 & 7.5 \\
\hline 8 & 3.3 & .5 & 96.7 & 14.5 \\
\hline 9 & 6.7 & 1 & 93.3 & 14 \\
\hline 10 & 3.3 & .5 & 96.7 & 14.5 \\
\hline 11 & 3.3 & .5 & 96.7 & 14.5 \\
\hline 12 & 0 & 0 & 100 & 15 \\
\hline 13 & 3.3 & .5 & 96.7 & 14.5 \\
\hline 14 & 26.6 & 4 & 73.4 & 11 \\
\hline 15 & 6.7 & 1 & 93.3 & 14 \\
\hline 16 & 13.3 & 2 & 86.7 & 15 \\
\hline 17 & 60 & 9 & 40 & 4 \\
\hline 18 & 3.3 & .5 & 96.7 & 14.5 \\
\hline 19 & 3.3 & .5 & 96.7 & 14.5 \\
\hline Mode & $3.3 \%$ & .5 & $96.7 \%$ & 14.5 \\
\hline
\end{tabular}

Table 1 depicts the teacher's use the target language and English on days of instruction during study and the mean percentage of language use. No data are reported for the first 
two days in the table because it was on these days when the pretest was administered. The mode of target language use of $96.7 \%$ is above the ACTFL recommendation of $90 \%$ target language use in the foreign language classroom (ACTFL, 2013). A day-by-day analysis of language use revealed that English was used for principled reasons. In other words, increases in the use of English occurred at critical points in the unit. For example, the increase in English use on Days 6 and 7 occurred at moments when the teacher determined it was necessary to realize the instructional goal of the lesson. On these days, the teacher used English $60 \%$ and $50 \%$ of the class time, respectively. On Day 6, the teacher was summarizing the content of Lesson 1 to ensure that students had a clear understanding of the concept of genre. On Day 7, the students were first introduced to the systematic deconstruction of the genre and were assigning names to the stages. Likewise, at the beginning of Lesson 4 on Day 14, the teacher used English during $26.6 \%$ of the class ensure the students' clarity about her prompts for identifying the purpose of the text and the hook phase. As the teacher recounted, she «used English to be certain that students could focus clearly on the task : writing in Spanish». On Day 17, the percentage of English use was again at the highest at $60 \%$. Given that Day 17 was the first day of joint construction of the touristic landmark description, it is not surprising that the teacher resorted to English because of the novelty of the process of co-creating a text with the students. Overall, the teacher's use of English corresponds to moments when the process was new to her and the students, assessment was necessary before moving on, or the instructional goal could not be adequately met through the target language.

\section{Discussion}

The experience of the teacher in the present study presents two major implications for a focus on language awareness through explicit training in genre and functional linguistics in language teacher preparation. The first is related to training teachers in approaches to genre-based instruction and assessment. The second is related to the use of the target language in the classroom when implementing a genre-based pedagogy. Both issues have implications for the development of the language awareness that is critical for developing plurilingual competencies of pre-service teacher, in-service teachers, and their students.

\section{1. Training teachers to use the tools of language}

The teacher in the present study learned to analyze key components of the functional grammar of the touristic landmark description genre. The scope of the language analysis to which the teacher was exposed was limited to a specific genre and highly controlled to meet the goals of this study. Yet, this minimal training in teaching the touristic landmark description genre yielded promising results regarding the effect of such training on teacher practice. Observational and interview findings revealed that the teacher began to apply her knowledge of genre to other units of study that she taught beyond the classroom involved in the present study. Two salient examples highlight the teacher's learning during the present study. First, the teacher modified the type of text that she asked third grade students to write so that the writing task was aligned with the reading task. Second, the teacher integrated the genre pedagogy into the existing reading and writing activities in a unit on traveling to the Caribbean. In other words, the Deconstruction, Joint Construction, and Independent Construction of texts had become 
the teacher's primary way of approaching the instruction of texts in Spanish. These outcomes related to teacher practice echo findings in the development of teachers of English as a second language (e.g., Achugar, Schleppegrell, \& Orteíza, 2007; Brisk \& Zisselsberger, 2011; Gebhard, 2010; Gebhard et al., 2007) in the United States. Collectively, these studies demonstrate the potential of teacher development that is informed by a comprehensive theory of language that leverages teacher learning to develop students' repertoire of academic literacy practices over time (Gebhard, 2010). These literacy practices are part of the range of spoken and written plurilingual acts, which are «situated in time, discourse, and are context based» (Oliveira \& Ançã, 2009, p. 405) and must be made visible to teachers over time through explicitly training. Thus, a critical component of teacher preparation that develops plurilingual competence is raising teachers' awareness of the functions of language in communicative contexts and providing opportunities for teachers to apply that awareness in planning and instruction.

\section{2. The role of the target language}

The present study offers some insight into the role of the target language in teaching academic literacy in the foreign language classroom. The teacher's use of Spanish in the unit of study varied depending on the instructional goal of a particular lesson. The use of English was purposive and clearly linked to instructional goals. Despite her relatively minimal use of English (mode $=3.3 \%$, with a high of $60 \%$ on two days of the 17 days of instruction), the teacher experienced a tension between maintaining target language use, guiding students through the interpretation of the text, and following the framework for the lessons outlined in the unit of instruction. Her desire to teach a lesson that adhered to the professional standard of at least $90 \%$ of instruction in the target language, as recommended by the ACTFL Target Language Position (ACTFL, 2013), and the novelty of the instructional approach contributed to the tension experience by the teacher. This tension echoes the findings of the research of Cammarata $(2009,2010)$, who found that teachers implementing content-based instruction (CBI) experienced a similar tension related to language and content as they integrated the approach into their practice. Notwithstanding the anxiety that the teacher experienced related to target language use, the mode percentage of instruction in Spanish was $97.7 \%$ over the 17 days of instruction, which exceeds the recommendation of ACTFL. However, it is possible that a clearer definition of expected target language use, particularly when implementing a new approach to instruction, may have relieved some of the tension experienced by the teacher. Cummins (2005, as cited in Gort, 2012) provides guidance in this regard, as he posited that :

while extensive use of the target language within foreign / second language and bilingual/immersion programs is clearly a useful and important instructional strategy, it should not be implemented in a rigid or exclusionary manner... .Students' [native language] is a powerful resource for learning and bilingual instructional strategies can usefully complement monolingual strategies to promote more cognitively engaged learning (p. 49).

Given the argument of Cummins and the tension related to target language on the part of the teacher, the findings indicate that the field - foreign language education in particular - needs to more clearly define the role of the target language in the foreign language classroom. Given the needs of standards-based instruction (Troyan, 2012), CBI (Tedick \& Cammarata, 2012), immersion education (Cammarata \& Tedick, 2012) and CLIL (e.g., 
Dalton-Puffer, 2007; Lyster \& Mori, 2006; Ruiz de Zarobe, 2013), a prudent question to pose might be : What is the principled use of the frst language in a given instructional situation Foreign language education might look toward bilingual education (e.g., Gort, 2006, 2012; Gort \& Pontier, 2012), which has investigated the code switching that occurs in bilingual classrooms, for guidance in responding to this question. Certainly, a growing number of researchers in foreign language education have underscored that an awareness of the functions of language among language teachers is critical in enabling what Cammarata and Tedick (2012) refer to as a linguistic «awakening» (p. 260-261) as they become more aware of the demands of balancing content and language. As their awareness of how language functions in context grows, it is likely that teachers will be empowered to make more principled decisions regarding when to use the target language and when to use the first language. Again, if a goal of plurilingualism is to develop plurilingual identities and abilities among students (e.g., Le Nevez, Hélot, \& Ehrhart, 2010), the agenda of teacher development likewise must be to develop among teachers an awareness of the role of the multiple languages and dialects that they will encounter in their classrooms.

\section{Conclusion}

In sum, the findings of the present study demonstrate the potential of genre theory and SFL to inform the work of language teacher preparation focused on developing language awareness among teachers. Awareness of the functions of language in context is one of the key considerations in developing plurilingual students who possess a flexible «repertoire of knowledge and skills with which [they can] move within, between, and across different languages and in linguistically diverse environments» (Le Nevez, Hélot, \& Ehrhart, 2010, pp. 9-10). Developing language awareness in teachers is a complex process. In one respect, the findings of the present study echo the research of content-based instruction (CBI) indicating that teachers struggle to use the target language to teach content and language simultaneously. Specifically, the findings reinforce the call for further research and professional development to investigate language use in the classroom in settings where teachers seek to integrate language and content (Cammarata \& Tedick, 2012; Tedick \& Cammarata, 2012). Such an approach to teacher education is essential as we prepare a «new generation of language educators equipped to monitor 'language development within the interactional space' (Fortune \& Tedick, 2008)». In another respect, the experience of the teacher as she implemented a genre-based pedagogy demonstrates that sustained work with genre and SFL can influence a language teacher's practice by raising the teacher's language awareness (Borg, 1994). Such awareness among language teachers is only one component of a wider, more comprehensive plurilingual awareness that develops teachers' understanding of the cultural and linguistic diversity among the learners in their classrooms (e.g., Le Nevez, 2010). As implied by García (2010) in her foreword to a recent volume on developing plurilingual competencies in teachers, this effort in Europe could be informed by the ongoing research and teacher development (García, 2009, 2010; Gort, 2006, 2012; Gort \& Pontier, 2012) that positions learners as «emergent bilinguals...who potentially could develop dual language and literacy abilities if supported in their immediate environments, including home and school» (Gort, 2012, p. 46). Certainly, the work of designing preparation programs that develop language teachers who can support the development of language awareness and a plurilingual identity is a top priority for all of 
us involved in language teacher development. In this regard, the plurilingual agenda calls for international collaborations in the design of teacher preparation that position all language learners, including teachers, as legitimate users of multiple languages and dialects (Troyan \& Sembiante, 2014).

\section{BIBLIOGRAPHY}

Achugar, M., Schleppegrell, M.J. \& Orteiza, T. (2007). Engaging teachers in language analysis : A functional linguistics approach to reflective literacy. English Teaching: Practice and Critique, 6(2), 8 $-24$.

American Council on the Teaching of Foreign Languages (ACTFL). Use of the target language in the classroom (2013). Alexandria, VA: Author. Retrieved from http://www.actfl.org/news/ position-statements/use-the-target-language-the-classroom-0

Beacco, J.-C. (2005). Languages and language repertoires: Plurilingualism as a way of life in Europe. Guide for the development of language education policies in Europe: From linguistic diversity to plurilingual education. Reference Study. Strasbourg, France : Council of Europe.

Beacco, J.-C. \& Byram, M. (2003). Guide for the development of language education policies in Europe: From linguistic diversity to plurilingual education. Strasbourg, France : Council of Europe.

Bernstein, B. (1996). Pedagogy, symbolic control and identity : Theory, research, critique. Lanham, MD : Rowman \& Littlefield.

Brisk, M.E. \& Zisselsberger, M. (2011). «We've let them in on the secret » : Using SFL theory to improve the teaching of writing to bilingual learners. In Lucas, T. (Ed.), Teacher preparation for linguistically diverse classrooms: A resource for teacher educators (pp. 11-126). New York : Routledge.

Borg, S. (2010). Language teacher research engagement. Language Teaching 43. P. 391 - 429. doi : $10.1017 / \mathrm{s} 0261444810000170$

Cammarata, L. (2009). Negotiating Curricular Transitions : Foreign Language Teachers' Learning Experience with Content-Based Instruction. Canadian Modern Language Review / La Revue canadienne des langues vivantes 65. P. 559 - 585. doi: 10.3138/cmlr.65.4.559

Cammarata, L. (2010). Foreign language teachers' struggle to learn content-based instruction. L2 Journal 2. P. 89 - 118. Retrieved from : http://escholarship.org/uc/item/8g91w2r7

Cammarata, L. \& Tedick, D. (2012). Balancing content and language in instruction: The experience of immersion teachers. Modern Language Journal 96. 251 - 269. doi: 10.1111/

j.1540-4781.2012.01330.x

Curtain, H. \& Dahlberg, C.A. (2010). Languages and children: Making the match (4th ed.). Boston, MA: Pearson.

Dalton-Puffer, C. (2007). Discourse in content and language integrated learning (CLIL) classrooms. Philadelphia : John Benjamins. 
Derewianka, B. (1991). Exploring how texts work. Rozelle, NSW Australia : Primary English Teaching Association.

Derewianka, B. (2003). Trends and issues in genre-based approaches. RELC Journal 34. P 133 - 154. doi: $10.1177 / 003368820303400202$

Derewianka, B. \& Jones, P. (2012). Teaching language in context. Melbourne : Oxford University Press.

Fang, Z. \& Schleppegrell, M.J. (2008). Reading in secondary content areas : A language-based pedagogy. Ann Arbor, MI : University of Michigan Press.

Fortune, T.W., \& Tedick, D. J. (Eds.). (2008). Pathways to multilingualism: Evolving perspectives on immersion education. Clevedon, UK : Multilingual Matters.

Garcia, O. (2009). Emergent bilinguals and TESOL : What's in a name ? TESOL Quarterly 43. P. 322 326. doi: 10.1002/j.1545-7249.2009.tb00172.x

Garcia, O. (2010). Foreword. In Le Nevez,, A., Helot, C. \& Ehrhart, S. (Eds.), Plurilinguisme et formation des enseignants : Une approche critique/Plurilingualism and teacher edcuation : A critical approach (pp. 1-4). Berlin: Peter Lang.

Gebhard, M. (2010). Teacher education in changing times : A Systemic Functional Linguistics (SFL) perspective. TESOL Quarterly, 44, 797 - 803. doi: 10.5054/tq.2010.237335

Gebhard, M., Harman, R. \& Seger, W. (2007). Reclaiming recess: Learning the language of persuasion. Language Arts, 84, 419 - 430.

Glisan, E.W., Adair-Hauck, B., Koda, K., Sandrock, S.P., \& Swender, E. (2003). ACTFL integrated performance assessment. Yonkers, NY: ACTFL.

Gort, M. (2006). Strategic codeswitching, interliteracy, and other phenomena of emergent bilingual writing: Lessons from first grade dual language classrooms. Journal of Early Childhood Literacy 6. P. 323 - 354. doi: 10.1177/1468798406069796

Gort, M. (2012). Code-switching patterns in the writing-related talk of young emergent bilinguals. Journal of Literacy Research, 44, 45 - 75. doi: 10.1177/1086296X11431626

Gort, M. \& Pontier, R. W. (2012). Exploring bilingual pedagogies in dual language preschool classrooms. Language and Education, 27, 223 - 245. doi: 10.1080/09500782.2012.697468

Halliday, M.A.K. (1975). Learning how to mean : Explorations in the development of language. London : Edward Arnold.

Halliday, M.A.K. (1993). Towards a language-based theory of learning. Linguistics and Education, 5, 93 - 116. doi: 10.1016/0898-5898(93)90026-7

Halliday, M.A.K. \& Matthiessen, C.M.I.M. (2004). An introduction to functional grammar (3rd ed.). London: Hodder Education.

Halliday, M.A.K. \& Matthiessen, C.M.I.M. (2013). Halliday's introduction to functional grammar. (4th ed.) New York : Routledge.

Le Nevez, A. (2010). Perceptions of diversity in the classroom: An action-research project on intercultural and linguistic awareness in Alsace A. Le Nevez, C. Hélot \& S. Ehrhart (Eds.), Plurilinguisme et formation des enseignants : Une approche critique/Plurilingualism and teacher education : A critical approach (pp. 173-193). Berlin: Peter Lang. 
Le Nevez, A., Hélot, C. \& Ehrahrt, S. (2010). Negotiating plurilingualism in the classroom. In Le Nevez, A. ; Hélot,C. \& Ehrahrt, S. (Eds.), Plurilinguisme et formation des enseignants : Une approche critique/Plurilingualism and teacher education: A critical approach (pp. 5-21). Berlin : Peter Lang.

Llinares, A. \& Whittaker, R. (2010). Writing and speaking in the history class: A comparative analysis of CLIL and first language contexts. In Dalton-Puffer,C. ; Nikula, T. \& Smit, U. (Eds.), Language use an language learning in CLIL classrooms, pp 125-143. Philadelphia, PA : John Benjamins.

Lorenzo, F. (2013). Genre-based curricula : Multilingual academic literacy in content and language integrated learning. International Journal of Bilingual Education and Bilingualism, 16, 375 388. doi: $10.1080 / 13670050.2013 .777391$

Lorenzo, F., Casal, S. \& Moore, P. (2010). The effects of content and language integrated learning in European education : Key findings from the Andalusian Bilingual Sections Evaluation Project. Applied Linguistics, 31, 418 - 442. doi: 10.1093/applin/amp041

Lyster, R. \& Mori, H. (2006). Interactional feedback and instructional counterbalance. Studies in Second Language Acquisition, 28, 269 - 300. doi: 10.1017/S0272263106060128

Martin, J.R. (1992). English text: System and structure. Amsterdam: Benjamins.

Martin, J.R. (2009). Genre and language learning: A social semiotic perspective. Linguistics and Education, 20, 10 - 21. doi: 10.1016/j.linged.2009.01.003

Martin, J.R., Christie, F. \& Rothery, J. (1987). Social processes in education: A reply to Sawyer and Watson (and others). In I. Reid (Ed.), The place of genre in learning, pp 58-82. Geelong: Center for Studies in Literacy Education, Deakin University (Typereader Publications 1).

Martin, J.R. \& Rose, D. (2007). Interacting with text : The role of dialogue in learning to read and write. Foreign Studies Journal, Beijing.

Martin, J.R. \& Rose, D. (2008). Genre relations : Mapping culture. London : Equinox.

Merriam, S.B. (1998). Case study research in education : A qualitative approach. San Francisco : JosseyBass.

Met, M. (1999). Content-based instruction: Defining terms, making decisions NFLC Reports. Washington, DC : The National Foreign Language Center.

Morton, T. (2010). Using a genre-based approach to integrating content and language in CLIL. In Dalton-Puffer, C. ; Nikula, T. \& Smit, U. (Eds.), Language use an language learning in CLIL classrooms, 81-104. Philadelphia, PA : John Benjamins. Philadelphia, PA : John Benjamins.

National Governors Association Center for Best Practices, Council of Chief State School officers. (2010). Common Core State Standards for English Language Arts and Literacy in History/ Social Studies, Science, and Technical Subjects. Washington, DC : Author.

Oliveira, A.L., \& Aanca, M.H. (2009). « I speak five languages » : Fostering plurilingual competence through language awareness. Language Awareness, 18, 403-421. doi : 10.1080/09658410903197355

Painter, C. (1984). Into the mother tongue : A case study in early language development. London : Pinter.

Painter, C. (1986). The role of interaction in learning to speak and learning to write. In Painter, C. \& Martin, J.R. (Eds.), Writing to mean : Teaching genres across the curriculum (pp 62-97). Applied Linguistics Association of Australia (Occasional Papers 9).

Pomphrey, C. \& Burley, S. (2009). Language awareness as methodology : Implications for teachers and teacher training. Language Awareness, 18, 422-433. doi: 10.1080/09658410903197314 
Rose, D. \& Martin, J.R. (2012). Learning to write, reading to learn: Genre, knowledge and pedagogy in the Sydney School. South Yorkshire, UK: Equinox.

Rothery, J. (1989). Learning about language. In Hasan, R. \& Martin, J.R. (Eds.), Language development : Learning language, learning culture (pp 199-256). Norwood, $\mathrm{NJ}$ : Ablex Publishing Company.

Rothery, J. (1996). Making changes : Developing an educational linguistics. In Hasan, R. \& Williams, G. (Eds.), Literacy in society (pp 86-123). London: Addison Wesley Longman.

Ruiz De Zarobe, Y. (2013). CLIL implementation: From policymakers to individual initiatives. International Journal of Bilingual Education and Bilingualism, 16, 231-243. doi:

$10.1080 / 13670050.2013 .777383$

Shrum, J.L. \& Glisan, E.W. (2010). Teacher's handbook : Contextualized language instruction (4th ed.). Boston, MA : Heinle Cengage Learning.

Tedick, D. \& Cammarata, L. (2012). Content and language integration in K-12 contexts : Student outcomes, teacher practices, and stakeholder perspectives. Foreign Language Annals 45(S1). P. S28 S53. doi: 10.111/j.1944-9720.2012.01178.x

Troyan, F. J. (2012). Standards for foreign language learning: Defining the constructs and researching learner outcomes. Foreign Language Annals, 45(S1), S118-S140. doi: 10.1111/ j.1944-9720.2012.01182.x

Troyan, F. J. (2013). Investigating a genre-based approach to writing in an elementary Spanish program. Unpublished doctoral dissertation. University of Pittsburgh : Pittsburgh, PA.

Troyan, F. J. (2014). Leveraging genre theory: A genre-based interactive model for the era of the Common Core State Standards. Foreign Language Annals, 47, 5-24. doi: 10.1111/flan.12068

Troyan, F. J. \& Sembiante, S. (2014). Teacher candidates' critical perspectives towards the functions of language and their role and identity as legitimate multilingual users. Manuscript in preparation.

Whittaker, R., Llinares, A. \& McCabe, A. (2011). Written discourse development in CLIL at secondary school. Language Teaching Research, 15, 343-362. doi: 10.1177/1362168811401154

Yi, Y. (2013). Adolescent multilingual writer's negotiation of multiple identities and access to academic writing: A case study of a Jogi Yuhak Student in a US high school. The Canadian Modern Language Review / La revue canadienne des langues vivantes, 69, 207-231. doi: 10.3138/cmlr.1381

\section{NOTES}

1. It is important to note that the development of plurilingualism is much more complex than developing a linguistic awareness, as the "plurilingual identity is very much intertwined with the individual's representation of him/herself as a plurilingual being" (Oliveira \& Ançã, 2009, p. 405). See Oliveira and Ançã (2009) for a discussion of the principles of a didactic approach plurlingualism (p. 407). 


\section{ABSTRACTS}

This article depicts the developing language awareness of a fourth grade teacher of Spanish as a foreign language in the United States as she implemented a genre-based pedagogy to teach students writing in Spanish. Given that language awareness has been identified as a fundamental aspect of developing a plurilingual identity, the present study investigates the influence of genre theory (Martin \& Rose, 2008) informed by systemic functional linguistics (SFL) on the teacher's awareness of language in her practice. Observational findings and interview data were triangulated and depict the teacher's developing awareness of genre, the influence of genre on her curriculum design, and her struggle to maintain the target language during the genre-based lessons. Key implications are shared for the preparation of language teachers who can foster the plurilingual identity of students.

Cet article décrit l'expérience de la prise en charge par un professeur d'espagnol langue étrangère d'un cursus centré sur la pédagogie par le genre auprès d'élèves américains de 9/10 ans («4th grade» aux Etats-Unis) apprenant à écrire en espagnol. Sachant que la sensibilisation à la langue joue un rôle essentiel dans le développement de l'identité plurilingue, l'article examine l'influence de la théorie du genre (Martin \& Rose, 2008) sur cet aspect de la pratique de l'enseignante. Les données de cette étude, issues de l'observation et de deux entretiens avec l'enseignante montrent comment celle-ci développe la conscience du genre, décrivent sa lutte pour maintenir la langue cible pendant l'enseignement du cursus, et font état de l'influence du genre sur l'élaboration de son programme d'enseignement. Les résultats de ce travail pourraient être réinvestis dans l'accompagnement des enseignants désireux de promouvoir le plurilinguisme chez les jeunes élèves.

\section{INDEX}

Mots-clés: enseignement des langues étrangères, formation des enseignants de langues étrangères, plurilinguisme, théorie du genre

Keywords: foreign language education, foreign language teacher preparation, genre theory, plurilingualism

\section{AUTHOR}

\section{FRANCIS JOHN TROYAN}

Assistant Professor, Foreign and Second Language Education, The Ohio State University 